ISSN: 2224-0616

Int. J . Agril. Res. Innov. Tech. 8 (2): 42-46, December 2018

DOI: https:// doi.org/ 10.3329/ijarit.v8i2.40554

Available online at https://ijarit.webs.com

https:// www.banglajol.info/index.php/ IJ ARIT

\title{
YIELD RESPONSE OF SELECTED IRRIGATED RICE VARIETIES TO VARYING N, P AND K FERTILIZER REGIMES
}

\author{
J. Chirchir ${ }^{*}$, G. Chemining'wa' ${ }^{2}$, F. Nzuve ${ }^{3}$ and R. Murori ${ }^{4}$
}

Received 24 September 2018, Revised 3 December 2018, Accepted 26 December 2018, Published online 31 December 2018

\begin{abstract}
Rice production has been inconsistent in Mwea irrigation scheme due to poor crop management practices and reduced soil fertility. Proper rice nutrition conserves the environment, increases sustained crop production, farmer's crop yield and profits. A field experiment was conducted at MIAD Center, in Kirinyaga County, during 2016-17 and 201718 to determine the response of rice varieties to different $\mathrm{N}, \mathrm{P}$ and $\mathrm{K}$ fertilizer treatments. The trial was conducted in randomized complete block design, with three replications of 13 $\mathrm{N}, \mathrm{P}$ and $\mathrm{K}$ fertilizer regimes as the main plots treatments and varieties Basmati 370 and BW 196 as the sub-plot treatment. The $\mathrm{N} \mathrm{kg} \mathrm{ha-1:} \mathrm{P}_{2} \mathrm{O} 5 \mathrm{~kg} \mathrm{ha}^{-1}: \mathrm{K}_{2} \mathrm{O} \mathrm{kg}^{-1} \mathrm{~h}^{-1}$ fertilizer treatment ratios used were: 00:00:00, 60:40:40, 80:60:60, 100:80:80, 60:40:00, 80:60:00, 100:80:00, 60:00:40, 80:00:60, 100:00:80, 00:40:40, 00:60:60 and 00:80:80. Plant height, number of tillers hill-1, panicle length, and grain yield responded positively to fertilizer application, but 1000-grain weight did not. Variety BW 196 recording shorter plants and panicles, more tillers hill-1, higher grain weight and yield than variety Basmati 370. 00:40:40, 00:60:60, 00:80:80, 60:40:00 and the no-fertilizer control treatments recorded the least number of tillers hill-1. 60:40:40, 80:60:60, 100:80:80, fertilizer treatments had longer panicles than the no fertilizer control and 00:40:40. Except for 100:80:00 and 00:40:40, in the first season and 60:40:00, 80:60:00, 100:80:00 in the second season, all the fertilizer regimes increased grain yield relative to the control. The highest grain yield was realized in fertilizer regime 80:60:60, 100:80:80, 80:00:60 and 100:00:80. 80:00:60 is the recommended fertilizer regime.
\end{abstract}

Keywords: Crop Productivity, Fertilizer Regimes, Varieties, Mwea

${ }^{1,2 \& 3}$ Department of Plant Science and Crop Protection, Faculty of Agriculture, University of Nairobi, P.O. Box 29053,
Nairobi, Kenya
${ }^{4}$ International Rice Research Institute (IRRI), Eastern and South Africa (ESA) Hub, P.O. Box 30709-00100, IRRI c/o ILRI,
Nairobi, Kenya
*Corresponding author's email: jedida.chirchir@gmail.com (J. Chirchir)

Cite this article as: Chirchir, J., Chemining'wa, G., Nzuve, F. and Murori, R. (2018). Yield response of selected irrigated rice varieties to varying N, P and K fertilizer regimes. Int. J. Agril. Res. Innov. Tech. 8(2), 42-46.

\section{Introduction}

Traditionally, rice crop was prominent only in Asia, but over the years, it has also gained prominence in Africa's farming systems and diet. In Africa, rice is ranked fourth after maize, sorghum and millet, in terms of acreage grown. Its production is ranked second after maize (FAOSTAT, 2012). Several studies have shown that Kenya has the capacity of producing over $9 t$ ha $^{-1}$ of rice (Saito et al., 2013). In spite of that, the mean rice yields in Kenya between the year 2005 and 2009, was 2.5 t ha-1 $^{-1}$ (Onyango, 2014). This translates to a yield gap of over 6.5 t ha $^{-1}$.

According to reports from MOA (2009), the rice production sector in Kenya faces several setbacks, such as: poor infrastructure, high costs of farm inputs and machinery, uncoordinated marketing, inadequate rice crop management skills, high disease incidences, land degradation and nutrient losses. In Mwea irrigation scheme, the average crop production has been fluctuating due to reduced soil fertility, soil degradation and use of inappropriate crop management practices by farmers (Nyamai et al., 2012). Formerly, farmers in Mwea used to burn one part of their farm and spread ashes across the paddy fields. Because of the increasing demand for animal feed, straw is baled and sold; hence, organic matter is transported to a different location. Husks are also disposed elsewhere after dehulling (Muhunyu, 2012). The mass transportation of organic matter from the rice fields, combined with permanent water logging and rice monoculture reduces the inherent capacities of the soil to supply nutrients, and hence results in long-term detrimental effects on crop production. 
Balanced application of inorganic fertilizers is important for increased yields and sustained production of quality rice. It aids in reducing injury from infestation of pests and diseases, and minimizes expenditures that are to be used in controlling them. Nutrient requirements vary with varying varieties of rice (Dobermann and Fairhurst, 2000). In Mwea, at least all farmers use inorganic fertilizers, with $86 \%$ using DAP (Diammonium Phosphate) as basal fertilizer, 93\% using SA (Sulphate of Ammonia) as a top dresser. Only 2\% use MOP (Muriate of Potash) as a basal fertilizer (Muhunyu, 2012). Irrespective of the soil nutrient status and rice variety planted, most farmers apply $50 \mathrm{~kg} \mathrm{acre}^{-1}$ of either DAP or SA, to their fields. Such application of blanket fertilizer could have significant negative effect on the performance and yield of rice. Good nutrition could lower the current rice yield gaps $\left(6.5 \mathrm{t} \mathrm{ha}^{-1}\right)$ in Kenya. Considering these perspectives, the current study was set up to monitor the response of selected rice varieties to varying nitrogen, phosphorus and potassium fertilizer regimes.

\section{Materials and Methods}

The present experiment was conducted for two seasons; between the years 2016 and 2018. It was setup in MIAD center, in Kirinyaga County. MIAD is located to the northeastern region of Nairobi, Kenya's capital, and to the southeastern part of Mount Kenya (Ngige, 2004). Before setting up the trial plots, soil at the experimental site was collected from different homogenous units, at two depths $(0-15$ and $15-30 \mathrm{~cm})$, and bulked into two samples. The soils were analyzed for macro and micronutrients, $\mathrm{pH}$, electrical conductivity and organic carbon. Very low levels of potassium (68.00, $37.10 \mathrm{ppm}$ ) and phosphorus (3.06, $0.93 \mathrm{ppm})$, and considerably low levels of Boron $(0.21,0.33 \mathrm{ppm})$ and zinc $(1.02,1.12 \mathrm{ppm})$ were reported at both depths.

Meteorological data was collected from MIAD meteorological station, during the research period. The highest rainfall $(481 \mathrm{~mm})$ was recorded in November 2017 and the lowest (0.00 $\mathrm{mm}$ ) in January 2017. The mean temperature ranged from 21.75 to $28.79^{\circ} \mathrm{C}$. The highest relative humidity was $86.47 \%$ (November 2018) and the lowest was $69.74 \%$ (J anuary 2017).

The experiment was conducted in randomized complete block design, with three replications of 13 nitrogen, phosphorus and potassium fertilizer regimes as the main plots treatments and varieties Basmati 370 and BW 196 as the sub-plot treatment. The $\mathrm{N} \mathrm{kg} \mathrm{ha}^{-1}: \mathrm{P}_{2} \mathrm{O} 5 \mathrm{~kg} \mathrm{ha}^{-1}: \mathrm{K}_{2} \mathrm{O} \mathrm{kg}$ ha1 fertilizer treatment ratios used were: 00:00:00, $60: 40: 40, \quad 80: 60: 60, \quad 100: 80: 80, \quad 60: 40: 00$, 80:60:00, 100:80:00, 60:00:40, 80:00:60, $100: 00: 80,00: 40: 40,00: 60: 60$ and 00:80:80. The sources of nitrogen, phosphorus and potassium fertilizer were Urea, Triple superphosphate (TSP) and Muriate of potash (MOP), respectively.
Each $9 \mathrm{~m}^{2}$ nutrient plot was bunded and lined with a 500 gauge polythene bag ( $45 \mathrm{~cm}$ deep), to minimize mixing of nutrients and to maintain a uniform water depth. Plants in each plot had a 20 $\mathrm{x} 20 \mathrm{~cm}$ spacing.

To monitor the response of the crop to varying inorganic fertilizer regimes, data was collected from a sample of 10 plants (IRRI, 2014). Observations on plant height and the number of tillers hill ${ }^{-1}$ were collected at 30 and 75 DAT. Plant height measurements were taken from the soil surface to the apex of the tallest panicle, excluding awns. The tiller count hill-1 ${ }^{1}$ was counted on the ten marked hills plot ${ }^{-1}$. At maturity, paddy rice was harvested, and dried to $14 \%$ moisture content. Grain yield was weighed and the weight of 1000 well developed seeds were also recorded. Using the 15th edition of Genstat software, the collected data was subjected to analysis of variance. The Least Significant Difference (LSD) test (at $\mathrm{P} \leq 0.05$ ) was used to compare means between treatments.

\section{Results and Discussion}

A positive response of varieties Basmati 370 and BW 196 to nitrogen, phosphorus and potassium fertilizer, in plant height, number of tillers hill-1, panicle length and grain yield was recorded in this study. This could be due to the low levels of these plant nutrients in the soils in the study area. In the present study applying 80:60:60, 100:80:80 and 100:00:80 fertilizer treatments augmented plant height relative to the nofertilizer control. $\mathrm{N}$ omission treatments $(00: 40: 40,00: 60: 60,00: 80: 80)$ did not have a significant effect on plant height relative to the no fertilizer control. The increased plant height in fertilizer regime 80:60:60 and 100:80:80 could be explained by the sufficient supply of rice nutrients. The inadequate supply of $\mathrm{N}$ in 00:40:40, 00:60:60, 00:80:80 resulted in plant heights resembling those of the no-fertilizer control (Table 1); because nitrogen deficiency must have disrupted metabolic processes of the plants (Dobermann and Fairhurst, 2000).

Fertilizer regime: 00:40:40, 00:60:60, 00:80:80, 60:40:00 and 00:00:00 registered the least number of tillers hill- -1 . The poor performance of the tillers could be due to inadequate nitrogen and potassium fertilizer in the soils of study. The good performance in N, P, K (60:40:40, 80:60:60, 100:80:80), N, P (60:40:00, 80:60:00, 100:80:00) and N, K (100:00:80 and 80:00:60) fertilizer regime (Table 2) could be explained by the increased uptake of nitrogen, phosphorus and potassium from the soils of study. Nitrogen stimulates plant growth (Doberman and Fairhurst, 2000). Potassium increases number of tillers hill-1 by improving the crops metabolic processes. Availability of phosphorus encourages development of roots and production of large healthy leaves (Plenet et al., 2000). 
Table 1. Effect of varying fertilizer regimes on the average plant height $(\mathrm{cm})$ of two rice varieties at 30 and 75 days after transplanting in first and second season at MIAD.

\begin{tabular}{|c|c|c|c|c|c|c|c|c|c|c|c|c|}
\hline & \multicolumn{6}{|c|}{ First season } & \multicolumn{6}{|c|}{ Second season } \\
\hline Fertilizers & \multicolumn{3}{|c|}{ Height 30-DAT } & \multicolumn{3}{|c|}{ Height 75-DAT } & \multicolumn{3}{|c|}{ Height 30-DAT } & \multicolumn{3}{|c|}{ Height 75-DAT } \\
\hline $\begin{array}{l}\mathrm{N}: \mathrm{P}_{2} \mathrm{O}_{5}: \\
\mathrm{K}_{2} \mathrm{O}\end{array}$ & $\begin{array}{l}\text { Bs } \\
370\end{array}$ & $\begin{array}{l}\text { BW } \\
196\end{array}$ & Mean & $\begin{array}{l}\text { Bs } \\
370\end{array}$ & $\begin{array}{l}\text { BW } \\
196\end{array}$ & Mean & $\begin{array}{l}\text { Bs } \\
370\end{array}$ & $\begin{array}{l}\text { BW } \\
196\end{array}$ & Mean & $\begin{array}{l}\text { Bs } \\
370\end{array}$ & $\begin{array}{l}\text { BW } \\
196\end{array}$ & Mean \\
\hline 00:00:00 & 19 & 15 & 17 & 86 & 40 & 63 & 39 & 37 & 38 & 103 & 46 & 75 \\
\hline $60: 40: 40$ & 24 & 19 & 21 & 102 & 47 & 74 & 42 & 41 & 42 & 109 & 61 & 85 \\
\hline $80: 60: 60$ & 23 & 20 & 22 & 100 & 53 & 76 & 50 & 42 & 46 & 117 & 58 & 88 \\
\hline $100: 80: 80$ & 24 & 20 & 22 & 102 & 54 & 78 & 45 & 43 & 44 & 114 & 59 & 87 \\
\hline $60: 40: 00$ & 21 & 18 & 20 & 95 & 47 & 71 & 42 & 39 & 41 & 98 & 49 & 73 \\
\hline 80:60:00 & 22 & 19 & 20 & 93 & 47 & 70 & 46 & 38 & 42 & 107 & 51 & 79 \\
\hline $100: 80: 00$ & 25 & 20 & 22 & 102 & 49 & 75 & 40 & 40 & 40 & 102 & 57 & 79 \\
\hline 60:00:40 & 21 & 19 & 20 & 94 & 49 & 72 & 44 & 40 & 42 & 110 & 53 & 81 \\
\hline 80:00:60 & 21 & 19 & 20 & 94 & 50 & 72 & 48 & 42 & 45 & 115 & 60 & 87 \\
\hline 100:00:80 & 23 & 20 & 22 & 105 & 53 & 79 & 41 & 41 & 41 & 113 & 64 & 89 \\
\hline $00: 40: 40$ & 19 & 17 & 18 & 93 & 43 & 68 & 41 & 43 & 42 & 110 & 54 & 82 \\
\hline $00: 60: 60$ & 20 & 16 & 18 & 94 & 44 & 69 & 45 & 39 & 42 & 109 & 51 & 80 \\
\hline $00: 80: 80$ & 20 & 17 & 19 & 89 & 44 & 66 & 45 & 39 & 42 & 113 & 54 & 83 \\
\hline Mean & 22 & 18 & 20 & 96 & 48 & 72 & 44 & 41 & 42 & 109 & 55 & 82 \\
\hline Fpr V & & $<.0 C$ & & & $<00$ & & & $<00$ & & & $<.00$ & \\
\hline Fpr F & & $<.00$ & & & $<00$ & & & 0.02 & & & $<.00$ & \\
\hline Fpr F*V & & 1.0 & & & 0.9 & & & 0.2 & & & 0.2 & \\
\hline $\operatorname{LSD}_{0.05} \mathrm{~V}$ & & 0.7 & & & $2.6^{*}$ & & & $1.5^{*}$ & & & $2.1^{*}$ & \\
\hline $\operatorname{LSD}_{0.05} \mathrm{~F}$ & & 1.9 & & & $6.5^{*}$ & & & $3.9^{*}$ & & & $5.5^{*}$ & \\
\hline $\begin{array}{l}\text { LSD } 0.05 \\
F^{*} V\end{array}$ & & NS & & & NS & & & NS & & & NS & \\
\hline CV\% & & 8.0 & & & 7.8 & & & 7.9 & & & 5.7 & \\
\hline
\end{tabular}

Fpr- F probability, LSD- Least significant difference at $\mathrm{P} 0.05, \mathrm{~V}$-variety, F-fertilizer regimes, F*V- interaction between Variety and Fertilizer regimes, NS- Not significant at $\mathrm{P}_{0.05}$, * -significant at $\mathrm{P}_{0.05}, \mathrm{CV}$ - co-efficient of variation Ratio of $\mathrm{N}$ : $\mathrm{P}_{2} \mathrm{O}_{5}: \mathrm{K}_{2} \mathrm{O}$ refers to $\mathrm{N} \mathrm{kg} \mathrm{ha}^{-1}: \mathrm{P}_{2} \mathrm{O}_{5} \mathrm{~kg} \mathrm{ha}^{-1}: \mathrm{K}_{2} \mathrm{O} \mathrm{kg}$ ha-1

Table 2. Effects of varying fertilizer regimes on the mean of tiller numbers hill-1 of two rice varieties at 30 and 75 days after transplanting in the first and the second season at MIAD.

\begin{tabular}{|c|c|c|c|c|c|c|c|c|c|c|c|c|}
\hline \multirow{3}{*}{$\begin{array}{c}\text { Treatments } \\
\mathrm{N}: \mathrm{P}_{2} \mathrm{O}_{5}: \mathrm{K}_{2} \mathrm{O}\end{array}$} & \multicolumn{6}{|c|}{ First season } & \multicolumn{6}{|c|}{ Second season } \\
\hline & \multicolumn{3}{|c|}{ Tillers 30} & \multicolumn{3}{|c|}{ Tillers 75} & \multicolumn{3}{|c|}{ Tillers 30} & \multicolumn{3}{|c|}{ Tillers 75} \\
\hline & $\begin{array}{c}\text { Bs } \\
370\end{array}$ & $\begin{array}{l}\text { BW } \\
196\end{array}$ & Mean & $\begin{array}{c}\text { Bs } \\
370\end{array}$ & $\begin{array}{l}\text { BW } \\
196\end{array}$ & Mean & $\begin{array}{c}\text { Bs } \\
370\end{array}$ & $\begin{array}{l}\text { BW } \\
196\end{array}$ & Mean & $\begin{array}{c}\text { Bs } \\
370\end{array}$ & $\begin{array}{l}\text { BW } \\
196\end{array}$ & Mean \\
\hline 00:00:00 & 3.6 & 4.8 & 4.2 & 12 & 24 & 18 & 4.8 & 6.9 & 5.8 & 14 & 23 & 18 \\
\hline $60: 40: 40$ & 4.6 & 6.1 & 5.4 & 17 & 35 & 26 & 5.5 & 6.7 & 6.1 & 19 & 29 & 24 \\
\hline 80:60:60 & 5.0 & 6.9 & 6.0 & 22 & 27 & 25 & 8.9 & 9.7 & 9.3 & 18 & 28 & 23 \\
\hline 100:80:80 & 5.7 & 7.7 & 6.7 & 18 & 36 & 27 & 7.3 & 7.4 & 7.4 & 19 & 29 & 24 \\
\hline $60: 40: 00$ & 4.2 & 6.7 & 5.5 & 16 & 28 & 22 & 5.4 & 7.1 & 6.3 & 19 & 23 & 21 \\
\hline 80:60:00 & 4.9 & 8.7 & 6.8 & 17 & 39 & 28 & 6.5 & 7.2 & 6.9 & 17 & 26 & 21 \\
\hline 100:80:00 & 5.7 & 7.6 & 6.7 & 20 & 33 & 26 & 4.4 & 6.9 & 5.7 & 17 & 29 & 23 \\
\hline $60: 00: 40$ & 3.7 & 5.7 & 4.7 & 17 & 30 & 23 & 6.2 & 8.1 & 7.2 & 16 & 26 & 21 \\
\hline 80:00:60 & 4.1 & 6.7 & 5.4 & 17 & 35 & 26 & 7.1 & 7.5 & 7.3 & 20 & 27 & 23 \\
\hline 100:00:80 & 4.7 & 5.9 & 5.3 & 18 & 32 & 25 & 4.3 & 5.7 & 5.0 & 19 & 30 & 24 \\
\hline 00:40:40 & 3.7 & 5.2 & 4.4 & 14 & 27 & 20 & 5.2 & 7.9 & 6.6 & 13 & 23 & 18 \\
\hline $00: 60: 60$ & 4.8 & 6.6 & 5.7 & 15 & 24 & 19 & 6.4 & 6.7 & 6.6 & 14 & 25 & 20 \\
\hline $00: 80: 80$ & 5.5 & 6.8 & 6.2 & 13 & 24 & 19 & 5.9 & 6.2 & 6.1 & 16 & 24 & 20 \\
\hline Mean & 4.6 & 6.6 & 5.6 & 17 & 30 & 23 & 6.0 & 7.2 & 6.6 & 17 & 26 & 22 \\
\hline Fpr V & \multirow{2}{*}{\multicolumn{3}{|c|}{$\begin{array}{l}<001 \\
<001\end{array}$}} & \multirow{2}{*}{\multicolumn{3}{|c|}{$<001$}} & \multicolumn{3}{|c|}{$<001$} & \multicolumn{3}{|c|}{$<.001$} \\
\hline Fpr F & & & & & & & \multirow{2}{*}{\multicolumn{3}{|c|}{0.8}} & \multirow{2}{*}{\multicolumn{3}{|c|}{0.6}} \\
\hline Fpr F*V & \multicolumn{3}{|c|}{$\begin{array}{c}<.001 \\
0.7\end{array}$} & \multicolumn{3}{|c|}{0.1} & & & & & & \\
\hline $\operatorname{LSD}_{0.05} \mathrm{~V}$ & \multirow{2}{*}{\multicolumn{3}{|c|}{$\begin{array}{c}0.5^{*} \\
11^{*}\end{array}$}} & \multirow{2}{*}{\multicolumn{3}{|c|}{$\begin{array}{l}1.9^{*} \\
49 *\end{array}$}} & \multirow{2}{*}{\multicolumn{3}{|c|}{$0.6^{*}$}} & \multicolumn{3}{|c|}{$1.3^{*}$} \\
\hline $\mathrm{LSD}_{0.05} \mathrm{~F}$ & & & & & & & & & & \multicolumn{3}{|c|}{$3.3^{*}$} \\
\hline $\operatorname{LSD}_{0.05} \mathrm{~F}^{*} \mathrm{~V}$ & \multicolumn{3}{|c|}{$\begin{array}{l}1.1^{*} \\
\mathrm{NS}\end{array}$} & \multicolumn{3}{|c|}{ NS } & \multicolumn{3}{|c|}{ NS } & \multirow{2}{*}{\multicolumn{3}{|c|}{$\begin{array}{c}\text { NS } \\
13.4\end{array}$}} \\
\hline CV\% & \multicolumn{3}{|c|}{17.5} & \multicolumn{3}{|c|}{17.9} & \multicolumn{3}{|c|}{20.2} & & & \\
\hline
\end{tabular}

Fpr- F probability, LSD- Least significant difference at $\mathrm{P} 0.05$, V-variety, F-fertilizer regimes, F*V- interaction between Variety and Fertilizer regimes, NS- Not significant at $\mathrm{P}_{0.05}$, * -significant at $\mathrm{P}_{0.05}, \mathrm{CV}$ - co-efficient of variation Ratio of $\mathrm{N}$ : $\mathrm{P}_{2} \mathrm{O}_{5}: \mathrm{K}_{2} \mathrm{O}$ refers to $\mathrm{N} \mathrm{kg} \mathrm{ha}^{-1}: \mathrm{P}_{2} \mathrm{O}_{5} \mathrm{~kg} \mathrm{ha}^{-1}: \mathrm{K}_{2} \mathrm{O} \mathrm{kg} \mathrm{ha}^{-1}$ 
60:40:40, 80:60:60, 100:80:80, N, P and K fertilizer regimes had significantly higher rice panicle lengths than the no fertilizer control and 00:40:40, in both seasons. Application of these fertilizer treatments may have improved the nutrient use efficiency of the rice crop; therefore increasing its chlorophyll content and enhancing proper assimilate translocation to reproductive parts, hence augmenting rice crop yield (Sarkar and Malik, 2001). Poor panicle development in 80:60:00, 100:80:00 could be have been due to the low (68 ppm) potassium levels in the study soils. Plots treated with fertilizer treatments:
00:00:00 and 00:40:40 could have been nutrient deficient resulting in poor development of panicles. Application of excess potassium and phosphorus where nitrogen was deficient (00:80:80) could have inhibited panicle development (Dobermann and Fairhurst, 2000). From the results of this study, fertilizer application had an insignificant effect on 1000grain weight of rice (Table 3). A thousand grain weight is not prone to effects by environmental factors; it is controlled genetically (Yoshida, 1981). This explains why BW 196 had higher 1000-grain weight than Bs 370.

Table 3. Effect of different fertilizer regimes on yield parameters of two rice varieties planted in the first and the second season, between August 2016 and February 2018 at MIAD.

\begin{tabular}{|c|c|c|c|c|c|c|c|c|c|c|c|c|}
\hline \multirow[t]{2}{*}{ Treatments } & \multicolumn{6}{|c|}{ First season } & \multicolumn{6}{|c|}{ Second season } \\
\hline & \multicolumn{3}{|c|}{ Panicle length (cm) } & \multicolumn{3}{|c|}{ Grain weight (g) } & \multicolumn{3}{|c|}{ Panicle length (cm) } & \multicolumn{3}{|c|}{ Grain weight (g) } \\
\hline $\mathrm{N}: \mathrm{P}_{2} \mathrm{O}_{5}: \mathrm{K}_{2} \mathrm{O}$ & Bs 370 & BW 196 & Mean & Bs 370 & $\begin{array}{l}\text { BW } \\
196\end{array}$ & Mean & Bs 370 & $\begin{array}{l}\text { BW } \\
196\end{array}$ & Mean & Bs 370 & $\begin{array}{l}\text { BW } \\
196\end{array}$ & Mean \\
\hline 00:00:00 & 21.70 & 18.96 & 20.33 & 20.70 & 28.70 & 24.70 & 24.16 & 20.64 & 22.40 & 21.20 & 26.40 & 23.80 \\
\hline $60: 40: 40$ & 23.30 & 19.56 & 21.43 & 20.40 & 28.50 & 24.40 & 24.44 & 22.12 & 23.28 & 21.60 & 26.60 & 24.10 \\
\hline $80: 60: 60$ & 22.43 & 21.70 & 22.07 & 21.30 & 28.60 & 24.90 & 25.36 & 21.90 & 23.63 & 19.80 & 26.80 & 23.30 \\
\hline $100: 80: 80$ & 23.50 & 20.26 & 21.88 & 20.50 & 29.10 & 24.80 & 24.68 & 21.83 & 23.26 & 19.30 & 26.70 & 23.00 \\
\hline 60:40:00 & 23.04 & 19.50 & 21.27 & 19.50 & 27.60 & 23.60 & 24.32 & 21.45 & 22.89 & 19.50 & 27.00 & 23.30 \\
\hline $80: 60: 00$ & 22.53 & 19.26 & 20.90 & 21.00 & 26.40 & 23.70 & 24.25 & 19.61 & 21.93 & 20.10 & 27.30 & 23.70 \\
\hline 100:80:00 & 22.93 & 18.70 & 20.82 & 19.30 & 27.70 & 23.50 & 24.63 & 20.75 & 22.69 & 19.90 & 26.10 & 23.00 \\
\hline 60:00:40 & 22.96 & 20.40 & 21.68 & 20.90 & 28.10 & 24.50 & 24.64 & 21.35 & 22.99 & 20.70 & 26.50 & 23.60 \\
\hline 80:00:60 & 22.63 & 20.40 & 21.52 & 20.50 & 29.70 & 25.10 & 25.56 & 21.97 & 23.77 & 20.20 & 27.00 & 23.60 \\
\hline 100:00:80 & 23.43 & 20.16 & 21.80 & 23.20 & 26.90 & 25.10 & 26.16 & 22.26 & 24.21 & 21.60 & 28.50 & 25.10 \\
\hline 00:40:40 & 22.10 & 19.20 & 20.65 & 19.80 & 30.20 & 25.00 & 24.33 & 21.23 & 22.78 & 21.60 & 27.10 & 24.40 \\
\hline 00:60:60 & 22.39 & 20.30 & 21.35 & 19.70 & 28.90 & 24.30 & 25.11 & 21.88 & 23.50 & 20.80 & 27.70 & 24.30 \\
\hline 00:80:80 & 22.26 & 19.73 & 21.00 & 21.00 & 30.10 & 25.60 & 24.41 & 21.22 & 22.81 & 21.70 & 28.10 & 24.90 \\
\hline Mean & 22.71 & 19.86 & 21.28 & 20.60 & 28.50 & 24.50 & 24.77 & 21.40 & 23.09 & 20.60 & 27.10 & 23.80 \\
\hline Fpr V & & $<001$ & & & $<001$ & & & $<001$ & & & $<001$ & \\
\hline Fpr F & & 0.03 & & & 0.5 & & & 0.03 & & & 0.5 & \\
\hline Fpr F*V & & 0.16 & & & 0.1 & & & 0.92 & & & 1.0 & \\
\hline $\operatorname{LSD}_{0.05} \mathrm{~V}$ & & $0.40^{*}$ & & & $0.75^{*}$ & & & $0.47^{*}$ & & & $0.76^{*}$ & \\
\hline $\operatorname{LSD}_{0.05} \mathrm{~F}$ & & $1.03^{*}$ & & & NS & & & 1.19* & & & NS & \\
\hline $\begin{array}{l}\mathrm{LSD}_{0.05} \\
\mathrm{~F}^{*} \mathrm{~V}\end{array}$ & & NS & & & NS & & & NS & & & NS & \\
\hline CV \% & & 4.11 & & & 6.70 & & & 4.40 & & & 5.60 & \\
\hline
\end{tabular}

Fpr- F probability, LSD- Least significant difference at $\mathrm{P}_{0.05}$, V-variety, F-fertilizer regimes, $\mathrm{F}^{*} \mathrm{~V}$ - interaction between Variety and Fertilizer regimes, NS- Not significant at $\mathrm{P}_{0.05}$, * -significant at $\mathrm{P} 0.05, \mathrm{CV}$ - co-efficient of variation Ratio of $\mathrm{N}$ : $\mathrm{P}_{2} \mathrm{O}_{5}: \mathrm{K}_{2} \mathrm{O}$ refers to $\mathrm{N} \mathrm{kg} \mathrm{ha}^{-1}: \mathrm{P}_{2} \mathrm{O}_{5} \mathrm{~kg}$ ha-1: $\mathrm{K}_{2} \mathrm{O} \mathrm{kg} \mathrm{ha}^{-1}$

In the current study, higher (4.86 t ha-1) mean grain yield was registered in BW 196 than Basmati 370 (4.04 tha-1). The yield registered for variety Bs 370 in the current study is in the range (4.1 to $6 \mathrm{t} \mathrm{ha}^{-1}$ ) reported by Ndiiri et al. (2013), from farmers' fields in Mwea. All the fertilizer treatments augmented grain yield relative to the control with an exception of 100:80:00 and 00:40:40, in the first season and 60:40:00, 80:60:00, 100:80:80 in the second season (Table 4). The highest grain yield was reported in fertilizer regime: 80:60:60, 80:00:60, 100:80:80 and 100:00:80 in both seasons. 80:00:60 is the best fertilizer regime for rice production in Mwea, because it costs less than the rest that exhibit equal performance. For the advantage of sustainable land use, 80:60:60 and 100:80:80 fertilizer treatment would be suitable. To develop more precise soil recommendations, future research should seek to shed light on how long fertilizer regimes, 80:00:60 can consistently produce high rice yield; without phosphorus becoming deficient. The possibility of alternating 80:00:60 and 80:60:60 in different growing seasons should also be checked to minimize chances of phosphorus deficiency in rice fields. 
Table 4. Effect of different fertilizer regimes on yield ( $t$ ha $\left.^{-1}\right)$ of two rice varieties planted in the first and the second season, between August 2016 and February 2018 at MIAD.

\begin{tabular}{|c|c|c|c|c|c|c|}
\hline \multirow[t]{2}{*}{ Treatments } & \multicolumn{3}{|c|}{ First season } & \multicolumn{3}{|c|}{ Second season } \\
\hline & \multicolumn{3}{|c|}{ Yield (t ha-1) } & \multicolumn{3}{|c|}{ Yield (t ha-1) } \\
\hline $\mathrm{N}: \mathrm{P}_{2} \mathrm{O}_{5}: \mathrm{K} 2 \mathrm{O}$ & Bs 370 & Bw 196 & Means & Bs 370 & Bw 196 & Means \\
\hline 00:00:00 & 2.42 & 3.27 & 2.85 & 3.96 & 4.44 & 4.2 \\
\hline $60: 40: 40$ & 3.95 & 3.83 & 3.89 & 4.74 & 5.98 & 5.36 \\
\hline 80:60:60 & 4.36 & 5.7 & 5.03 & 4.71 & 6.12 & 5.41 \\
\hline $100: 80: 80$ & 4.19 & 4.22 & 4.21 & 4.82 & 6.13 & 5.48 \\
\hline 60:40:00 & 3.72 & 4.06 & 3.89 & 3.54 & 4.68 & 4.11 \\
\hline $80: 60: 00$ & 3.6 & 4.33 & 3.96 & 3.93 & 4.69 & 4.31 \\
\hline 100:80:00 & 3.7 & 3.41 & 3.56 & 3.63 & 5.13 & 4.38 \\
\hline 60:00:40 & 3.71 & 4.12 & 3.92 & 4.7 & 5.18 & 4.94 \\
\hline $80: 00: 60$ & 4.16 & 5.82 & 4.99 & 4.97 & 6.26 & 5.62 \\
\hline $100: 00: 80$ & 3.67 & 5.09 & 4.38 & 4.57 & 6.08 & 5.33 \\
\hline $00: 40: 40$ & 3.1 & 3.46 & 3.28 & 4.1 & 5.91 & 5.01 \\
\hline $00: 60: 60$ & 4.27 & 3.34 & 3.81 & 4.3 & 5.72 & 5.01 \\
\hline $00: 80: 80$ & 3.79 & 3.82 & 3.81 & 4.4 & 5.5 & 4.95 \\
\hline Mean & 3.74 & 4.19 & 3.97 & 4.34 & 5.52 & 4.93 \\
\hline FprV & \multicolumn{3}{|c|}{0.02} & \multicolumn{3}{|c|}{$<.001$} \\
\hline Fpr F & \multicolumn{3}{|c|}{$<001$} & \multicolumn{3}{|c|}{$<.001$} \\
\hline Fpr F*V & \multicolumn{3}{|c|}{0.17} & \multicolumn{3}{|c|}{0.34} \\
\hline LSD $0.05 \mathrm{~V}$ & \multicolumn{3}{|c|}{$0.34^{*}$} & \multirow{2}{*}{\multicolumn{3}{|c|}{$0.21^{*}$}} \\
\hline LSD $0.05 \mathrm{~F}$ & \multirow{2}{*}{\multicolumn{3}{|c|}{$0.85^{*}$}} & & & \\
\hline LSD $0.05 F^{*} \mathrm{~V}$ & & \multicolumn{2}{|l|}{ NS } & \multirow{2}{*}{\multicolumn{3}{|c|}{$\begin{array}{c}\text { NS } \\
9.23\end{array}$}} \\
\hline CV \% & \multicolumn{3}{|c|}{18.53} & & & \\
\hline
\end{tabular}

Fpr- F probability, LSD- Least significant difference at $\mathrm{P} 0.05, \mathrm{~V}$-variety, F-fertilizer regimes, $\mathrm{F}^{*} \mathrm{~V}$ - interaction between Variety and Fertilizer regimes, NS Not significant at $\mathrm{P}_{0.05}$, ${ }^{*}$-significant at $\mathrm{P} 0.05, \mathrm{CV}$ - co-efficient of variation Ratio of $\mathrm{N}: \mathrm{P}_{2} \mathrm{O}_{5}: \mathrm{K}_{2} \mathrm{O}$ refers to $\mathrm{N} \mathrm{kg} \mathrm{ha}^{-1}: \mathrm{P}_{2} \mathrm{O}_{5} \mathrm{~kg}$ ha-1: $\mathrm{K}_{2} \mathrm{O} \mathrm{kg}^{-1}$

\section{Conclusion}

Increased fertilizer application resulted in increased plant height, number of tillers ${ }^{-1}$ hill, length of the panicles and grain yield of rice. The highest grain yield was reported in fertilizer regimes: 80:60:60, 80:00:60, 100:00:80 and $100: 80: 80$. 80:00:60 is the best fertilizer regime for rice production in Mwea.

\section{References}

Dobermann, A. and Fairhurst, T. 2000. Rice: Nutrient disorders and nutrient management. Potash and Phosphate Institute (PPI), Potash Institute of Canada (PPIC) and International Rice Research, Singapore. pp. 13-82.

FAOSTAT. 2012. Food and Agriculture Organization Corporate Statistical Database. http:// Faostat.fao.org (accessed on July $\left.30^{\text {th }}, 2017\right)$.

IRRI. 20114. Standard Evaluation System for rice (SES), 5th edition. Los Baños (Philippines): International Rice Research Institute. pp. 1114.

MOA. 2009. National rice development strategy 2008-2018. Information and documentation services, Kenya Agricultural Research Institute, Ministry of Agriculture, Nairobi p.6.

Muhunyu, J.G. 2012. Is doubling rice production in Kenya by 2018 achievable? J. Dev. Sust. Agric. 7: 46-54.

Ndiiri, J.A. Mati, B.M., Home, P.G. and Odongo, B. 2013. Water productivity under the system of rice intensification (SRI) from experimental plots and farmer surveys in Mwea, Kenya. Taiwan Water Conserv. 61 (4): 63-75

Ngige, K.J. 2004. An economic analysis of rice production in Mwea irrigation scheme. M.Sc. Thesis, School of Agriculture, University of Nairobi. 119p.

Nyamai, M.B., Mati, M., Home, P.G., Odongo, B., Wanjogu, R. and Thuranira, E.G. 2012. Improving land and water productivity in basin rice cultivation in Kenya through System of Rice Intensification. Agric. Eng. Int. CIGR J. 14 (2): 1-9.

Onyango, A.O. 2014. Exploring options for improving rice production to reduce hunger and poverty in Kenya. World Environ. 4(4): 172-179.

Plenet, D. Mollier, A. and Pellerin, S. 2000. Growth analysis of maize field crops under phosphorus deficiency. Radiation use efficiency, biomass accumulation and yield components. Plant and Soil. 224: 259-272.

Saito, K. Nelson, A. Zwart, S.J . Niang, A., Sow, A. Yoshida, H. and Wopereis, M.C. 2013. Towards a Better Understanding. Realizing Africa's Rice Promise, Centre for Agriculture and Bioscience International. 188p.

Sarkar, R.K. and Malik, G.C. 2001. Effect of foliar spray of $\mathrm{KNO}_{3}$ and $\mathrm{Ca}\left(\mathrm{NO}_{3}\right)_{2}$ on grass pea (Lathyrus sativus L.) grown in rice fallows. Lathyrus Lathyrism Newsl. 2: 47- 48.

Yoshida, S. 1981. Fundamentals of rice crop science. International Rice Research Institute (IRRI), Manilla, Philipines. pp. 41248. 